
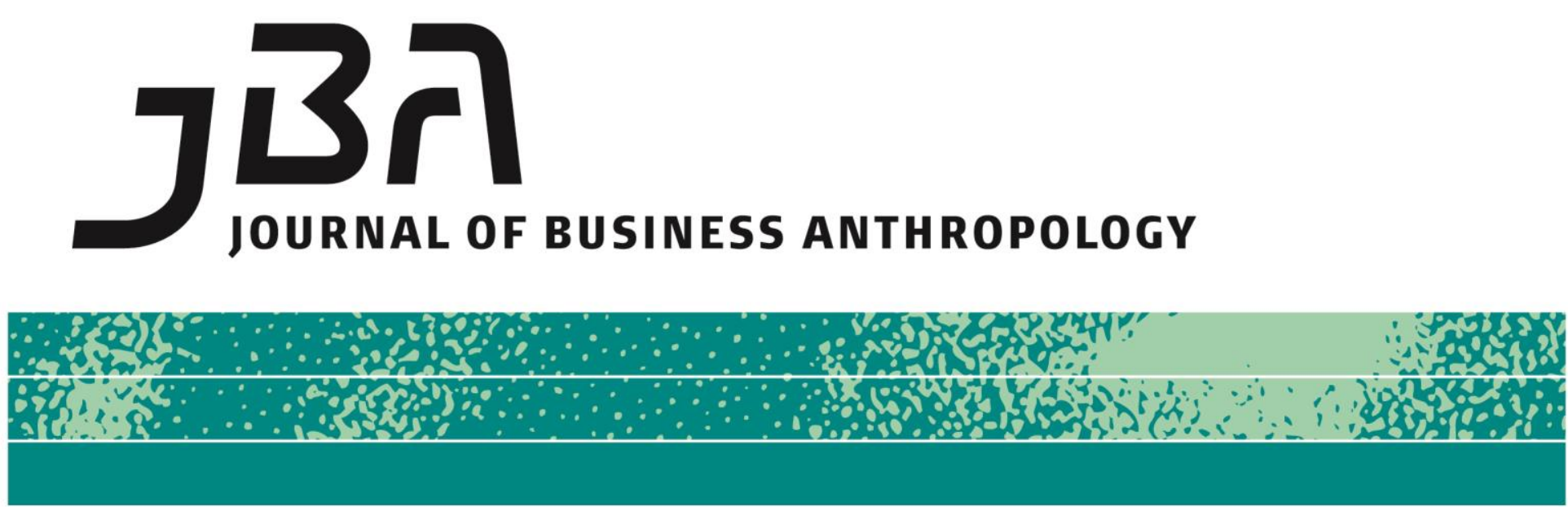

\title{
Guiding Change as President of the Board of Trustees: Learning from the Liminal Drama of It All
}

\author{
Elizabeth K. Briody
}

\begin{abstract}
Organizational-culture change has been of interest to scholars and practitioners for decades, though little empirical data has contributed to our understanding of ritual transitions. By contrast, transitions for individuals, but not organizations, have been examined through the theoretical lenses of ritual process. This article builds on both literatures to explore planned change in an assisted living and nursing care community. I led an effort, as President of the Board of Trustees, to establish philanthropy as a core element of the organizational culture at a time when the long-term-care sector had become increasingly competitive. Participant observation, documentary data and discussions, along with the roles I played, resulted in this account. My term of office was marked by ambiguity, inaction, polarization, and conflict. I distinguish among three types of "liminal" or transitional periods, using van Gennep and Turner's works as a foundation. I illustrate the relationship between liminality and the resistance and interventions that emerged within the Board and Leadership Team, drawing implications for ritual theory-particularly, liminality and social drama. The practical lessons from this experience, depicted in the Countering Resistance
\end{abstract}

Page 1 of 33

JBA Special Issue 2: 105-137, Spring 2016

(C) The Author(s) 2016 ISSN 2245-4217

www.cbs.dk/jba 
Model, should be helpful to other organizations and leadership groups in mitigating their own transition difficulties.

\section{Keywords}

Organizational-culture change, organizational transitions, liminality, resistance, social drama

\section{Introduction}

This article tells a tale of hope and promise overwhelmed by discord and futility. It focuses on the behavior of the Board of Trustees of a U.S.-based nonprofit organization during a period of planned change. As President, I led the development (fundraising and capital campaign) and marketing efforts. Despite my expertise in organizational-culture change in large business operations, my yearlong term in office did not result in significant change. With the benefit of hindsight, I wanted to explore and explain the cultural issues and draw lessons that would be useful to organizations experiencing transition difficulties.

\section{Planned organizational-culture change}

Organizational-culture change is typically an arduous process filled with aspirations and current certitudes, twists and turns, progress and breakdowns. While it can occur unexpectedly and unintentionally, it is often planned and implemented by organizational leaders. However, planned organizational-culture change is often incomplete, aborted, or generally unsuccessful. (Small group functioning and change has been modeled and tested with better results [cf., Bonebright 2010; Tuckman and Jensen 1977]). Mergers and acquisitions, and joint ventures have faced challenges in unifying disparate firms into larger, well-performing corporate wholes (Rottig et al. 2013; Meschi and Wassmer 2013; Weber et al. 2011). When attempts have been made to assemble internal groups or partners for an assignment, the results have not always been successful-particularly if little or no attention is paid to organizationalculture differences (Ferraro and Briody 2013; Boussebaa 2009). Resistance often emerges, evident in increased tension, delays, rework, and cost. Resistance can appear anywhere, including among the leadership. Kotter's early work underscores the "countervailing forces" and "behind-the-scenes struggle" that occur when leaders are not unified in their approach to change (1996:6).

More recent work in organizational-culture change confirms the importance of achieving consensus and mitigating resistance. Cameron and Quinn's (2011) “competing values framework" is intended to help organizational members reach consensus using preset culture types. Briody and her colleagues (2014) use "insider" perspectives to identify 
the "old way" in contrast to an ideal future. They find that organizations cope with as many as seven distinct obstacles to change, five of which pertain to resistance including ethnocentrism, cross-cultural conflict, and cultural drift. Burke's (2014) preventative approach suggests avoiding a "we-they process between change leaders and change recipients" (359) and cultivating trust. All these works offer recommendations for tackling change-related issues but they do not present a detailed examination of organizational interactions during the throes of change. Understanding the conditions when consensus and resistance emerge, and their interplay with other cultural elements, can inform the planning, implementation, and maintenance of organizational-culture change. Moreover, such experiences can provide useful lessons for organizational learning.

\section{Ritual transitions}

To understand cultural sequences during organizational-culture change, I turned to the work of classical theorists. Van Gennep (1960:189) focused on personal transitions: "For groups, as well as for individuals, life itself means to separate and to be reunited, to change form and condition, to die and to be reborn." People participate in ceremonies in which they "pass from one defined position to another which is equally well defined" (p.3) associated with "rites of entrance, waiting, and of departure - that is, as rites of passage" (p.25). During the transitional or middle phase, the individual "wavers between two worlds" (p.18), subject to "liminal (threshold) rites" (p.21). Van Gennep equated the phrase "liminal rites" with "rites of transition" (p.11) but did not specifically define liminality.

Unlike van Gennep, Turner pointed to ambiguity as the most salient attribute of liminality. He described it as "a fertile nothingness, a storehouse of possibilities...a striving after new forms and structure..." (1990:12). He applied the concept to people, situations, and periods of time:

Liminal entities are neither here nor there; they are betwixt and between...As such, their ambiguous and indeterminate attributes are expressed by a rich variety of symbols in the many societies that ritualize social and cultural transitions. Thus, liminality is frequently likened to death, ...to invisibility, to darkness...(2007:95).

Indeed, liminal transitions have "few or none of the attributes of the past or coming state" (2007:94). Role inversion or status suspension occurs during liminal periods with an egalitarian community spirit (described as communitas) typically forming among those experiencing the transition.

Additionally, Turner introduced the concept of the social drama, defined as "an objectively isolable sequence of social interactions of a 
conflictive, competitive, or agonistic type" (1988:33). As a social process, he argued it consisted of four phases:

1. Breach-in which a norm or rule is broken (such as a challenge to authority);

2. Crisis-during "which seeming peace becomes overt conflict and covert antagonisms become visible" and factions form and solidify (1982:70);

3. Redress-when actions mitigate or limit the breach, though there is the potential for "reversion to crisis" (1988:35);

4. Reintegration or Schism-"reconciliation of the contending parties or their agreement to differ" (1982:10).

Ritual and social dramas are tightly connected during the redress phase, described as "a liminal time" (1982:75). Turner included "personal and social conflict" (1990:11) as a type of redressive ritual. He considered a social drama to be a largely political process involving "competition for scarce ends-power, dignity, prestige, honor, purity-by particular means and by the utilization of resources that are also scarce" (1982:71-72). The central players in social dramas act as faction or clique leaders.

Other writers also have captured important attributes of transitions. Douglas (1966) argued that a transitional state-a "marginal period" (p.120)-is associated with danger "simply because transition is neither one state nor the next, it is undefinable" (p.119). Those in transition remain "in danger" until they transition into their new status. Garsten (1999:606), like Turner, emphasized the ambiguous quality of these "liminal personae ('threshold people')" as well as their condition. She found the liminal phase challenges the existing structure: temporary work became increasingly common and permanent. Moeran (2006) alludes to the presence of liminality when describing the redressive phase of a social drama in a Japanese advertising agency. Employees began "wooing certain members of the client company," agreeing to personnel changes "should the client decide to rule in the agency's favor" (pp.6667). Similarly, Malefyt and Morais (2012:43) emphasize the liminal quality of interactions between account managers and creatives in advertising; they summarize: "negotiations ensue, and battles rage."

Key differences in the characteristics of the organizational-change and ritual-process literatures are depicted in Table 1. Ritual analysis has been underemployed in explaining organizational-culture change, though it has been used to describe work practices and processes and the emergence of new forms of work in contemporary societies. By juxtaposing the organizational and ritual literatures-including the notion of social drama-new questions about transitions emerge that have relevance for theory as well as practice: 
- What place do resistance and consensus along with interventions play during an organization's liminal periods?

- What organizational strategies are employed to break out of transition and reengage with relevant publics?

- What lessons can be learned from attempts at organizationalculture change by applying ritual analysis?

I address these questions by exploring one organization's attempt at organizational-culture change.

\begin{tabular}{|c|c|c|}
\hline & $\begin{array}{c}\text { Organizational-Change } \\
\text { Literature }\end{array}$ & Ritual Process Literature \\
\hline Participants & $\begin{array}{l}\text { Organizational, including } \\
\text { special role for leadership } \\
\text { groups }\end{array}$ & Individuals and groups \\
\hline $\begin{array}{l}\text { Features of } \\
\text { Participant } \\
\text { Condition }\end{array}$ & $\begin{array}{l}\text { Inescapable, often scary, and } \\
\text { associated with conflict due } \\
\text { to potential impact on roles } \\
\text { and power }\end{array}$ & $\begin{array}{l}\text { Liminal, ambiguous, } \\
\text { dangerous, and can be } \\
\text { associated with conflict }\end{array}$ \\
\hline $\begin{array}{l}\text { Initial Participant } \\
\text { Reaction }\end{array}$ & Usually resistance & Usually acceptance \\
\hline Participant Status & In flux as role changes occur & $\begin{array}{l}\text { Changed, suspended, or } \\
\text { inverted, with others not } \\
\text { participating directly in the } \\
\text { ritual }\end{array}$ \\
\hline $\begin{array}{l}\text { Participant } \\
\text { Relationships }\end{array}$ & $\begin{array}{l}\text { Often disconnected, one from } \\
\text { the other }\end{array}$ & $\begin{array}{l}\text { Communitas (i.e., egalitarian } \\
\text { community spirit) with others } \\
\text { in the same situation }\end{array}$ \\
\hline Timing & $\begin{array}{l}\text { Generally planned to respond } \\
\text { to external risks or } \\
\text { opportunities }\end{array}$ & $\begin{array}{l}\text { Aligned with the life cycle or } \\
\text { community cycle }\end{array}$ \\
\hline $\begin{array}{l}\text { Markers of } \\
\text { Transition Period }\end{array}$ & $\begin{array}{l}\text { Less clarity around start } \\
\text { point and variation in clarity } \\
\text { around end point }\end{array}$ & $\begin{array}{l}\text { Typically well-defined start } \\
\text { point and end point }\end{array}$ \\
\hline $\begin{array}{l}\text { Cultural Context of } \\
\text { Transition Period }\end{array}$ & $\begin{array}{l}\text { Combination of external and } \\
\text { internal pressure to change }\end{array}$ & $\begin{array}{l}\text { Clarity around start point and } \\
\text { end point }\end{array}$ \\
\hline $\begin{array}{l}\text { Duration of } \\
\text { Transition Period }\end{array}$ & $\begin{array}{l}\text { Sequenced steps or stages } \\
\text { over an extended period of } \\
\text { time }\end{array}$ & $\begin{array}{l}\text { Sequenced steps or stages in } \\
\text { which duration varies }\end{array}$ \\
\hline $\begin{array}{l}\text { Specific } \\
\text { Knowledge } \\
\text { Surrounding } \\
\text { Outcome } \\
\end{array}$ & Generally not known a priori & Generally known a priori \\
\hline
\end{tabular}

Table 1: Key transition characteristics in the literature 


\section{Data and methods}

\section{Data collection}

I rely primarily on three data collection methods: participant observation, documents, and discussions. I was a participant observer at the long-term-care community LifeTree (a pseudonym) between January 2010 and March 2014 through my Board roles: member, Secretary, and President. I draw upon a particular eighteen-month period for this article: my last three months as Secretary, twelve months as President, and first three months following my presidency as a member once again.

I led or participated in meetings of the Board, Executive Committee (consisting of the President, Vice President, Secretary, and Treasurer), the Development Committee, and the Marketing Committee; the Executive Director participated in all meetings. Agendas for these meetings were prepared, committee updates, financial statements, and operations reports distributed, and minutes taken. I took close-toverbatim notes at these meetings. Email exchanges with Board members and selected members of the Leadership Team (Executive Director and her direct reports) were part of the documentary data. In addition, I participated in numerous discussions with Board and Leadership Team members, and the leaders of other long-term-care communities.

Supplementary data also informed my understanding of LifeTree's organizational culture. During my first two years as a Board member, I conducted a study of LifeTree's "culture story" (Briody and Briller, forthcoming), documenting the past, present, and ideal future. The Board sponsored this project, with agreement and support from the Leadership Team. During this same period, my family volunteered in LifeTree's pet therapy program. On other occasions I went alone to visit with residents, play or manage bingo, participate in photo and video shoots, and attend annual community functions. The various "lived experiences" that I had and the "connections" I made while part of the LifeTree community might be considered "intimate ethnography" (RylkoBauer, 2014) or "autoethnography" (Jones et al. 2013) in which the researcher intentionally includes him/herself as a focal point, relying heavily on personal materials such as documents, photos, and interviews to confirm personal interpretations (Chang, 2008).

\section{Data analysis}

Content analysis was the primary analytic technique I used to identify and analyze the themes and patterns pertaining to Board matters. I plotted resident census over time, compared presidential visions, and created a time line of key decisions. I analyzed my personal experiences and interactions, situating them within the broader patterns of organizational activity. I examined Board initiatives and decisions within the context of changes affecting LifeTree's viability as an organization. Lessons were 
revealed from which I created a model to understand LifeTree retrospectively.

\section{Background and setting}

\section{Marketplace conditions}

Some forces, such as the decline of three-generation households in the U.S., motivate seniors (or their family members acting on their behalf) to reside in assisted living or nursing care communities. However, such changes have coincided with the recession of the late 2000s and falling housing prices, reducing incentives for seniors to move to senior communities. Such factors contribute to a reduced number of new residents in communities such as LifeTree. When seniors change their residence, they frequently move to facilities operated by large, for-profit chains and characterized by sizeable architectural footprints, entrance lobbies with high ceilings, and lovely furnishings and plants. The state of the facility and its grounds seem to be a critical factor in the choice of a long-term-care community. Indeed, discussions with prospective LifeTree residents and/or their families suggest the assumption: if the physical plant is well cared for, the residents must be as well. Such places present a stark contrast to, and are competitors of, the smaller and older long-term-care communities like LifeTree.

\section{Organizational circumstances}

LifeTree is a small, independent, licensed senior community that was established as a mission of the Episcopal Church in a northern U.S. state. The Episcopal Bishop plays a limited role. Today a slight majority of residents is Roman Catholic, not Episcopalian. About 75 percent of the 110-bed facility is designated for assisted living and the remainder for basic nursing care. The culture story study demonstrated the high value placed on caring relationships. Indeed, relationship strength has been supported by the low employee turnover rate, particularly among directcare staff, which averaged seventeen percent between 2011 and 2014.

In mid-2012, I worked with a small group on a SWOT (Strengths, Weaknesses, Opportunities, Threats) analysis that I hoped would raise Board awareness and prompt planning and change. When I began my presidency, no strategic plan was in place, a critical tool to guide future direction at nonprofits (Renz 2010).

LifeTree was a hierarchically-structured organization. The Board President, in conjunction with the Executive Director and Director of Clinical Operations, were the key decision makers. The management style was directive, with employees taking direction from their supervisors, and Board members seemingly content to allow the Board President and Executive Committee to manage operations. 
Stories from the culture story study indicate that when LifeTree opened its doors nearly 50 years ago, many of the residents drove cars, managed their own finances, and were physically mobile. By 2014, residents were significantly older and frailer, averaging 91 years. Independent living no longer existed, and with it, a key feeder system disappeared. Occupancy of the nursing care section had held relatively steady over time (see Figure 1). However, in assisted living, a downward trend began during the mid-2000s and eventually led to the shuttering of a wing and several additional rooms/apartments. Assisted living, the key remaining feeder system, experienced a 19-percent reduction during the field period.

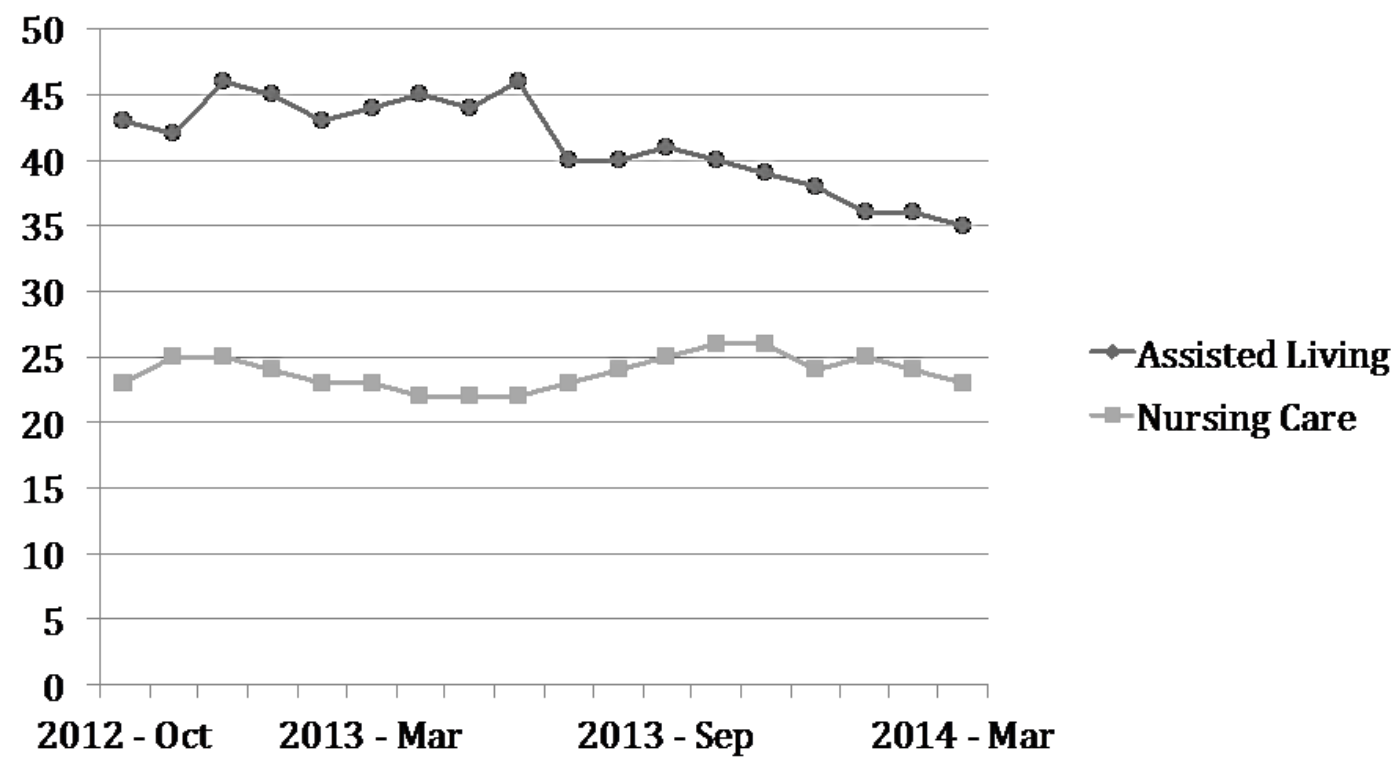

Figure 1: Resident census (October 2012 - March 2014)

Throughout its history, LifeTree has relied largely on resident fees to cover expenses. It is a private-pay organization, meaning that U.S. government funding such as Medicare or Medicaid is not accepted. No financial support has come from the Episcopal Church, no endowment has been established, and no annual or legacy-giving campaigns have taken hold. Any donations have been small and sporadic.

As resident statistics changed, cash flow was increasingly compromised. In the mid-2000s, LifeTree explored affiliation options with other retirement communities but ultimately withdrew "because we were afraid of losing our culture" stated a former Board President. A few years later, a marketing effort was initiated which included new promotional materials for prospective residents. However, it did not lead to any significant improvement in the census.

Culture story study participants repeatedly referred to the need for updating the lobby, exterior walkways, woodwork, and bathrooms. 
Recent phone discussions with prospective residents/family members revealed similar perspectives about the building and grounds. However, the most daunting challenge facing LifeTree has been the installation of a sprinkler system required by state regulators by 2019 .

There have been three new Executive Directors since 2010. Among the remaining 10 Leadership Team members, only three have worked continuously at LifeTree since 2010 . The most recent downward trend in the resident census began in September 2013 when the Activities Director resigned. Membership on the Board also has fluctuated with three Board Presidents-one each in 2012, 2013, and 2014-and seven other changes within the officer roles.

I believed valuable lessons could be identified from LifeTree's experience. Given the internal and external conditions, I wondered what actions might have been taken to build on the strengths and alleviate the challenges. Two lessons related to the value of strategic planning emerged from this background period (see Table 2).

\begin{tabular}{|l|l|}
\hline Issue & Lesson \\
\hline $\begin{array}{l}\text { No strategic plan } \\
\text { in place }\end{array}$ & $\begin{array}{l}\text { Initiate a strategic planning effort. Suggest and encourage key stakeholders to } \\
\text { participate in the creation of a strategic plan for the organization. Develop consensus } \\
\text { around the need to initiate change, expanding the discussion to encompass the direction of } \\
\text { the change and the conditions and processes related to it. The plan should 1) include a } \\
\text { SWOT analysis, 2) set goals and objectives, 3) prioritize changes for the near and long-term, } \\
\text { 4) establish criteria for measuring and achieving success, and 5) put in place a process for } \\
\text { using the strategic plan to guide decision making. }\end{array}$ \\
\hline $\begin{array}{l}\text { No framework for } \\
\text { Board consensus }\end{array}$ & $\begin{array}{l}\text { Seek validation and support for the finalized strategic plan. Communicate the plan's } \\
\text { focus to the appropriate stakeholder groups within the broader community. Use the plan } \\
\text { as a mechanism for raising awareness of new initiatives and other changes, building a } \\
\text { "brand image" for the organization's products or services, and extending networks to } \\
\text { secure resources, sponsorship, and other assistance. The momentum for change increases } \\
\text { with external support for the organization. }\end{array}$ \\
\hline
\end{tabular}

Table 2: Lessons about strategic planning prior to transition

\section{Mixed messages during presidential transition}

It was time for the Board President to step down. The by-laws limited members to two three-year terms and the President was completing his sixth year. With no one volunteering, and a potential Board leadership issue looming, I agreed to serve.

\section{Perceived alignment in vision for organizational change}

In the second half of 2012, the Board began to establish philanthropy as a core element of LifeTree culture. Board members voted to fill a Board member vacancy with a development expert who soon became Chair of the new Development Committee. This individual began introducing development insights and strategies at Board meetings: "If you ask people for money, they'll give you ideas; if you ask people for ideas, they 
will give you money." He also suggested Board members "think about a significant reach" in terms of a donation, yet at the same time "give at whatever level you feel comfortable with...We start with ourselves." Several Board members responded with year-end donations. In addition, another Board member proposed, and others quickly agreed, to hire a Development Director as part of Life Tree's Leadership Team.

The outgoing President's perspective seemed consistent with my own that philanthropy and marketing needed to occur in parallel. For example, at the November 2012 Board meeting, he stated, "We are going in a new direction as a Board. We will need a long-term focus that takes advantage of (the Development Director's) skill set." One month earlier, he pointed out that because about 65 percent of the residents were referred by family and friends, "We need to market to them."

\section{Disquieting decisions and initial indicators of resistance}

Concurrently however, turmoil and disagreement appeared. During the October 2012 Board meeting, the President introduced a motion to eliminate all development and marketing funds to achieve a balanced 2013 budget. I objected, arguing that the Board had brought in a new Board member because of his philanthropic expertise and that this individual would need access to such funds. Ultimately, a new motion was made and carried to eliminate funds for the Development Director position but not other development expenses. When the Development Director began her job in January 2013, her salary came from general operations.

Two other salient events occurred prior to my Presidency. First, during the November 2012 Board meeting, the President stated that he would like to "stay involved with the Board of Trustees and in the day-today operations." He turned to face the Executive Director and asked in a loud voice, "Do you feel I help you with (operations)?" Indeed, the Executive Director had relied extensively on him; he typically spent many hours/week at LifeTree. The Board voted to allow him to participate as a non-voting member in Board and Executive Committee meetings after his term as President ended.

Second, I met with the Executive Director in December 2012. She addressed me in what I perceived as a directive, accusatory tone. She asserted that her "whole Leadership Team was upset because I had been asking questions." In a relationship-building spirit, I had reached out to a few members of the Leadership Team and spoke to one of them the day before. My goals were to get their thoughts on LifeTree's future, find out how the Board could support them, and seek their advice as I began my new role. All knew me due to my Board role and the culture story study. The Executive Director insisted that I should have spoken with her first. Her reaction surprised me, especially since I routinely saw the outgoing 
President conversing with employees. However, I quickly decided not to speak with any other employees. As I left her office, she called out to me: "Let me give you a piece of advice that someone once gave me: 'Go slow!'”

The concept of hierarchy plays out in both examples. The Past President used his long tenure and dedicated volunteer work on Life Tree's operations to convince the Board that he should stay engaged, despite by-law limits. The Executive Director was able to admonish me without concern for reprisal by virtue of her senior leadership role and her insider status. The angst expressed by both individuals called attention to the change in leadership continuity and their potential loss of power and influence.

\section{Lessons}

Cultural contradictions were at play during my three-month transition to Board President. Inconsistencies appeared in what certain Board members said, in what decisions they made, in how they interpreted the by-laws, and in how the Executive Director began treating me differently. In particular, the Executive Director's rebuke appeared out of place given that I was about to become her boss. Not only was I experiencing ambiguity and frustration, but the trust and support I assumed that I had from the entire Board seemed compromised. I felt that I was in a liminal state with ideas and energy, yet facing challenges before I took office. Table 3 documents lessons learned during my presidential transition. 


\begin{tabular}{|c|c|}
\hline Issue & Lesson \\
\hline $\begin{array}{l}\text { Dismissal of } \\
\text { inconsistencies }\end{array}$ & $\begin{array}{l}\text { Assess stakeholder communication (verbal and nonverbal). Listen to the way in which } \\
\text { stakeholders frame and convey their expectations, beliefs, and assumptions. Take note of } \\
\text { any inconsistencies between what they say and what they do - including their nonverbal } \\
\text { reactions to proposed ideas and opposing arguments. Analyzing mixed messages will be } \\
\text { useful in understanding stakeholder perspectives as well as the extent of variation in those } \\
\text { perspectives. }\end{array}$ \\
\hline $\begin{array}{l}\text { Interaction } \\
\text { breakdown }\end{array}$ & $\begin{array}{l}\text { Keep the lines of communication open. Approach perceived differences of opinion by } \\
\text { seeking to understand the various points of view. Take the time to get to know those } \\
\text { individuals, with an eye to building the relationship. Listen to what they say, as well as } \\
\text { what they do not say. Talk about their concerns. Consider their knowledge and expertise. }\end{array}$ \\
\hline $\begin{array}{l}\text { Lack of } \\
\text { understanding }\end{array}$ & $\begin{array}{l}\text { Put yourself in the shoes of the key stakeholders. Think through the incentives and } \\
\text { interests of the key stakeholders. Imagine the future from their role in or association with } \\
\text { the organization. Estimate how realistic and successful a new initiative might be given } \\
\text { these constraints. }\end{array}$ \\
\hline $\begin{array}{l}\text { Inadequate } \\
\text { engagement }\end{array}$ & $\begin{array}{l}\text { Learn how the organization works. Figure out what the division of labor is, who needs to } \\
\text { be involved in decision making, and how change occurs. The informal hierarchy may be the } \\
\text { powerhouse behind organizational functioning. If so, then being "technically" in charge of a } \\
\text { particular function such as the role of a Board officer may mean that the power lies } \\
\text { elsewhere. }\end{array}$ \\
\hline $\begin{array}{l}\text { Hidden land } \\
\text { mines and } \\
\text { treasures }\end{array}$ & $\begin{array}{l}\text { Note the obstacles to change and the enablers that might facilitate it. Pay attention to } \\
\text { the barriers that can impede innovation and protect the status quo such as ethnocentrism, } \\
\text { cultural contradictions, and cultural drift. Identify the positive cultural processes that can } \\
\text { help break down those barriers including maintaining healthy relationships, cultivating } \\
\text { work ethic and pride, and setting clear expectations. Knowledge of the obstacles and } \\
\text { enablers will lead to more informed decision making. }\end{array}$ \\
\hline $\begin{array}{l}\text { Overreaching } \\
\text { objectives }\end{array}$ & $\begin{array}{l}\text { Decide which changes are critical to the success of new initiatives. Vision, } \\
\text { competency, and enthusiasm are insufficient for effective leadership. New, large-scale } \\
\text { initiatives require the support of key stakeholders. Focus primarily on substance issues } \\
\text { with some attention to process issues, but not process issues exclusively. }\end{array}$ \\
\hline
\end{tabular}

Table 3: Lessons in understanding the changing cultural context

\section{Ongoing conflict}

I was formally elected President at the January 2013 Board meeting. During the first few months, I worked with selected Board members to plan and conduct a new Board member orientation, participated in meetings with the new Development Director and Development Committee, and interacted and exchanged emails with the Board and key members of the Leadership Team.

\section{A sharp turn in vision with little vocalized support}

Tensions with the Executive Director had not dissipated. My notes state that I felt she had been "rude, dismissive, and non-cooperative," even as I sought a weekly standing meeting with her or information on LifeTree policies pertaining to the Board. Two other Board members who supported my leadership direction complained about their own interactions with her.

I asked the Past President to mediate a meeting between the Executive Director and me. My hope was to reconcile our differences and find common ground. During the meeting, the Executive Director stated that she found the results of the culture story study "personally critical" of 
LifeTree leadership. Her statement surprised me both because the study had been done two years before, and because the Board had praised it. We covered other topics before I summarized my view that LifeTree's survival and health depended on a combination of development and marketing strategies. I noted no verbal or nonverbal communication to suggest that either agreed.

I faced a similar reaction when I presented my vision for the Board's work at the February Board meeting. When I emphasized "working collaboratively across roles" (Board to staff) and launching the development and marketing work quickly, there were neither comments nor questions of a substantive nature. Instead, silence prevailed.

I began to flip-flop from a state of tension and silence (when with the Past President and Executive Director) to an alternate state of excitement and energy (when with the Development Committee). I began contemplating the differences in presidential visions and subsequently created Table 4.

\begin{tabular}{|c|c|c|}
\hline & Past President Vision & President Vision \\
\hline Focus of the Vision & $\begin{array}{l}\text { Internal - Methodologically seek cost } \\
\text { reductions attending to day-to-day } \\
\text { operations } \\
\text { - External - Some sporadic and limited } \\
\text { efforts in marketing and development }\end{array}$ & $\begin{array}{l}\text { External - Initiate parallel tracks of } \\
\text { development and marketing with } \\
\text { emphasis on a capital campaign }\end{array}$ \\
\hline Time Orientation & Short-term future ( $0-5$ years $)$ & Long-term future (5-10 years) \\
\hline $\begin{array}{l}\text { Expectations for Board } \\
\text { Members }\end{array}$ & $\begin{array}{l}\text { Attend monthly Board meetings, offering } \\
\text { input and advice } \\
\text { - Participate in other LifeTree activities and } \\
\text { events based on own interest and time }\end{array}$ & $\begin{array}{l}\text { - Lead development campaign with } \\
\text { donation of "significant reach" } \\
\text { - Collaborate with other Board members } \\
\text { and staff on at least one committee } \\
\text { - Serve as spokesperson and advocate in } \\
\text { wider community }\end{array}$ \\
\hline Management Style & Directive, outgoing, hierarchical & Collaborative, energized, egalitarian \\
\hline
\end{tabular}

Table 4: Comparison of presidential visions

The Past President had spent 2012 assessing LifeTree's budget, figuring out ways of reducing expenditures, and streamlining operations. He worked hand-in-hand with the Executive Director. He oversaw her work, sometimes "coaching" and sometimes instructing her; she took direction from him. Board members understood that the Past President was LifeTree's chief decision maker as well as someone devoted to its mission.

My vision centered on improving LifeTree's long-term health by establishing a new tradition of philanthropy, and reinvigorating efforts to attract new residents. Although I knew that some Board members and the Executive Director had expressed either trepidation or resistance to this vision, I hoped to motivate and inspire as many as possible in the revitalization. It seemed to be the next logical path to a bright future, now that operating expenses had been reduced. 


\section{Lessons}

The proposed development strategy, complete with capital campaign, represented a significant departure from the past. Neither the Past President nor the Executive Director had development experience. In retrospect, it would have been helpful to confer with them repeatedly about their concerns and involve them to a greater extent in the early planning (see Table 5).

\begin{tabular}{|l|l|}
\hline Issue & Lesson \\
\hline $\begin{array}{l}\text { Too divergent in } \\
\text { scope }\end{array}$ & $\begin{array}{l}\text { Strive for consensus on what to do and how to do it. Sound out key stakeholders. } \\
\text { Identify common ground. A set of talking points or a document incorporating distinctive } \\
\text { viewpoints, such as Table 4, can foster productive dialogue. Tie that dialogue to future } \\
\text { goals, including those associated with the strategic plan, to open the way for creative } \\
\text { problem solving and a set of shared solutions. }\end{array}$ \\
\hline $\begin{array}{l}\text { Inappropriate } \\
\text { pushback }\end{array}$ & $\begin{array}{l}\text { Limit the number of simultaneous changes. Too many changes may be viewed poorly by } \\
\text { stakeholders as overwhelming or unproven. Consider a staged or staggered approach to } \\
\text { evaluate how new programs and processes are working and to maximize the chances of } \\
\text { acceptance. }\end{array}$ \\
\hline $\begin{array}{l}\text { Resistance to } \\
\text { hierarchy }\end{array}$ & $\begin{array}{l}\text { Assess alignment in managerial styles. Opposing styles (e.g., authoritative vs. } \\
\text { collaborative) reflect clashes in values and differences in expectations and assumptions. } \\
\text { Such dissimilarity can result in processes that are protracted, changeable, and ambiguous, } \\
\text { with few tangible outcomes. Talk openly about the anticipated future, given the contrasting } \\
\text { styles. Model a collaborative and cooperative relationship. }\end{array}$ \\
\hline
\end{tabular}

Table 5: Lessons in bridging the past and present with the future

\section{The struggle over firing and hiring}

Within eight weeks of being hired, the Development Director resigned, setting in motion a long period of deliberation for the Board (see Figure 2). Many Board members surmised the Executive Director's hierarchical and micromanagement style would be a detriment to attracting other development professionals. A Board decision in April to "go into Executive Session" (i.e., without the Executive Director) was made to enable them to speak freely about the resignation. However, the decision caused an immediate reaction from the Past President who angrily shouted for several minutes and instructed the Executive Director to leave the room; she did, slamming the door behind her. At the close of the meeting, a Board member referred directly to the disruption. The minutes read: "Stirling (a pseudonym) offered a prayer of reconciliation." 


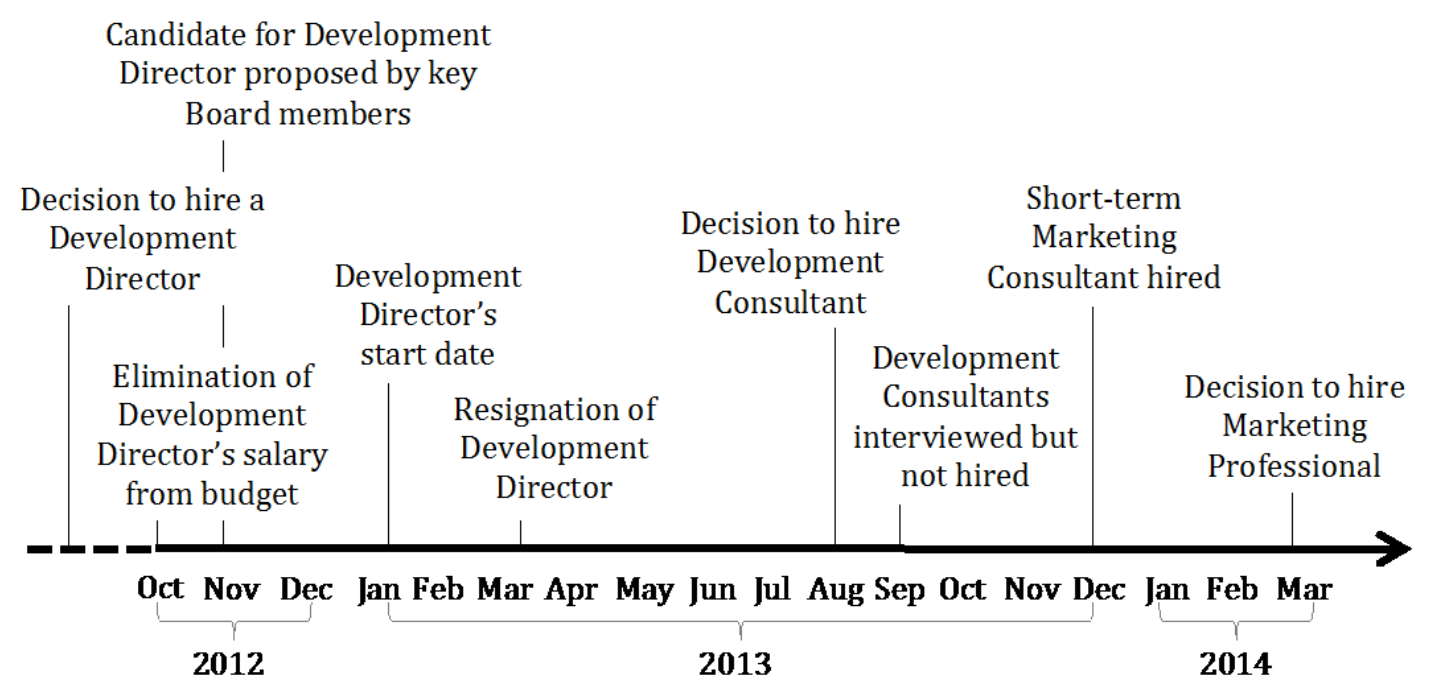

Figure 2: Decision-making swings in professional hiring

Two months later in June the Executive Director's job performance was again called into question, this time by the Treasurer who considered himself the "keeper" of the by-laws and Robert's Rules of Order-a guide for running effective meetings (www.robertsrules.org). He informed the Executive Director, in the presence of the Executive Committee and Past President: "You serve at the pleasure of the Board. There is no certainty about your position." Due to the difficulties in filling senior managerial positions in small, independent, long-term-care communities, even those officers who decried the Executive Director's job performance expressed a continued reluctance to let her go. Those serving on the Executive Committee and I hoped that this reprimand would incent the Executive Director to improve her performance.

The Development Committee articulated a rationale that any new development professional should be a consultant to the Board, not a LifeTree employee. Board turmoil continued as a result and was exacerbated when the Development Committee Chair suggested that each Board member "give or get" LifeTree $\$ 25,000 /$ year. Over the summer, many Board members indicated their unwillingness to invest time, effort, and/or money in leading a development effort at LifeTree.

Ultimately, the Board reached consensus and interviewed owners of three small consulting firms at the September Board meeting. While subsequent Board discussion revealed positive reactions to all three firms, a number of members expressed concern about their own ability to support whichever firm was selected. Their comments represented a "softer" version of the "I didn't sign up for this" plaint that had been filtering through Board discussions and emails. The consultants stressed that they would need access to Board member networks for potential sources of donations, and would need to work with Board members to cultivate prospective donors. 
As I listened to Board member reaction, it was clear to me that the development vision was at risk of collapse approximately one year after it was launched; indeed, within a few weeks, four Board members resigned, followed in October by two others. Looking around the room, I could see little energy for what would be required of the Board; the liminality linked to my Presidency was coming to a close. At the meeting's end, the Vice President stated the following:

I don't know how, why, or when. Something has happened here. I can't put my finger on it. When we were called (to serve), we didn't say we would create havoc. Maybe it is what we have done or failed to do. We should have said, 'Let's compromise.' We failed in our mission ... (For) our homework assignment let's ... give real honest thought to how this facility will maintain itself in the short and long-term. Let there be peace on earth and let it begin with me.

This statement was intended to be conciliatory and had that effect. However, with the exception of the Vice President, only those in favor of the development vision were in attendance.

A marketing resurgence began when the Board's Vice President introduced the Executive Director to a marketing professional; the latter was hired as a consultant in December 2013 and as a Leadership Team member three months later (see Figure 2). My tenure as President ended in January 2014. The Vice President assumed the Presidential role following a Board vote, though not without controversy; he tried to include the Past President in his slate of officers, but failed. Nevertheless, a new Presidential vision dedicated solely to marketing had been launched. 


\begin{tabular}{|c|c|}
\hline Issue & Lesson \\
\hline No goal setting & $\begin{array}{l}\text { Keep Board and organizational responsibilities separate. Boards have many } \\
\text { responsibilities including setting direction, ensuring adequate resources, maintaining } \\
\text { accountability, and providing general oversight of organizational activities. Organizational } \\
\text { leaders are charged with executing the strategic plan and addressing operational and } \\
\text { employee matters. Maintain this separation of responsibilities unless or until operational } \\
\text { and staff issues are negatively affecting the organization's ability to achieve its long-term } \\
\text { goals. }\end{array}$ \\
\hline $\begin{array}{l}\text { Insufficient on- } \\
\text { site interaction }\end{array}$ & $\begin{array}{l}\text { Create excitement around a shared future. Gather input from diverse stakeholders so } \\
\text { that they have a stake in contributing to both short-term and long-term organizational } \\
\text { solutions. Ensure that their input is incorporated into the strategic plan. Implementation } \\
\text { of the plan is energizing and easier with organizational buy-in. }\end{array}$ \\
\hline $\begin{array}{l}\text { No recognition or } \\
\text { "after-action" } \\
\text { reviews }\end{array}$ & $\begin{array}{l}\text { Celebrate early "wins" and identify how they were achieved. Publicly acknowledge a } \\
\text { successful start to the change process. Such acknowledgment helps raise the visibility of } \\
\text { the initiative. Evaluate the key steps taken to achieve those "wins" so that organizational } \\
\text { learning results and the efforts required to attain them can be recognized. }\end{array}$ \\
\hline $\begin{array}{l}\text { Inadequate } \\
\text { solicitation of } \\
\text { issues }\end{array}$ & $\begin{array}{l}\text { Address concerns to unify stakeholders. Organizational change can result in "winners" } \\
\text { and "losers." Some may be rewarded or experience little disruption, while others may be } \\
\text { adversely affected by change processes. Still others may perceive that they have to act } \\
\text { against their own self-interest for the long-term good of the organization. Respond to } \\
\text { stakeholder questions as completely as possible, provide new information in a timely } \\
\text { fashion, and counter the rumor mill. }\end{array}$ \\
\hline $\begin{array}{l}\text { No expectations } \\
\text { established }\end{array}$ & $\begin{array}{l}\text { Hold individuals accountable for the roles they play. Discussions with employees and } \\
\text { colleagues about their performance should take place when the first signs of problems } \\
\text { appear. Inadequate attention to job tasks or misconduct should not be ignored or avoided } \\
\text { since it has the potential to worsen over time and affect organizational functioning. } \\
\text { Listening, offering support, establishing goals, and following up can be valuable strategies } \\
\text { for handling poor performance. Put in place strategies such as training, incentives, and } \\
\text { sanctions to support a change in behavior. }\end{array}$ \\
\hline $\begin{array}{l}\text { No conflict- } \\
\text { mitigation plan }\end{array}$ & $\begin{array}{l}\text { Beware of the cumulative effect of conflict. Work hard to address tensions as they } \\
\text { surface. Ongoing disagreements and disputes can exhaust energy levels, harden positions, } \\
\text { damage relationships, and reduce the likelihood that people will want to stay engaged in } \\
\text { the organization's initiatives and future plans. }\end{array}$ \\
\hline
\end{tabular}

Table 6: Lessons in building consensus

\section{Lessons}

Effective nonprofit governance requires consensus. Calling attention to the process by which the group will work together can help (see Table 6). For example, establishing goals and expectations, along with ways to achieve them, has the potential to motivate involvement. If members believe that their views and expertise are valued, they are more likely to be supportive of the overall effort.

\section{Board cliques extend to the Leadership Team}

After only two months on the job, the Development Director requested a meeting saying that there was "virtually no support for development" at LifeTree. She reported that during her first week the Executive Director said: "Don't bother the Board with your work. We'll use the staff for fundraising." She mentioned "snide comments" from Leadership Team members about how often she went out to lunch-a common practice in development circles with donors. She indicated "the total lack of trust 
among the leadership staff"-all of which led to her resignation the following day.

I experienced a similar reaction when I spoke with the Leadership Team after becoming President: few smiles, questions, or comments, some with arms folded across the chest, and some speaking under their breath to those next to them. I concluded that resistance to my approach had spread beyond the Past President and Executive Director to selected members of the Leadership Team - including the Director of Clinical Operations and at least one other individual.

Another cultural clue appeared in a statement I requested from the Development Director after she resigned. She wrote: "I feel the current culture at LifeTree really reflects the Us and Them mentality. The Board appears to be divided into two groups and the staff has taken camps. There is the St. Dunstan's group (a pseudonym for one of the founding Episcopal parishes) and then there is everyone else." The Board was divided based on perceived importance of development, although this pattern correlated highly with church affiliation and prior personal/professional networks.

By September 2013, I observed that all Board members had informally self-selected into one of two cliques; the four Executive Committee officers were equally divided. One clique continued to place high priority on development, with secondary importance on marketing. One Board member stated, "We rely on operations and not on a culture of philanthropy. We have a lot of groundwork to do to identify donors." The other clique prioritized operations and marketing, with no attention to development as in this statement: "Marketing is much more important than development. My frustration is we are not concentrating on residents."

A related pattern pertained to the close ties among the Executive Director, Past President, and Director of Clinical Operations. The latter two were married to each other and had hired the Executive Director. Many Board members considered the Past President and Director of Clinical Operations critical to LifeTree because of their administrative expertise and two-decades-long association with it. Additionally, the Director of Clinical Operations held a nursing home administrator's license and served as a back up during Executive Director turnover. The trio worked largely independently of Board input and oversight and continued to manage facility operations as if the Past President were still Board President.

\section{Lessons}

Just as important as building consensus is keeping the organization unified. Over time I realized the power of disunity and fragmentation caused by cliques and learned key lessons as a result (see Table 7). Blind 
perseverance toward an end goal is insufficient. It is necessary to cultivate relationships continually, address concerns, and problem solve around cliques.

\begin{tabular}{|l|l|}
\hline Issue & Lesson \\
\hline $\begin{array}{l}\text { Dissemination } \\
\text { plan; too little, too } \\
\text { late }\end{array}$ & $\begin{array}{l}\text { Prepare the organization for change. Familiarize employees, customers, suppliers, and } \\
\text { other stakeholders with the organization's new direction, goals, practices, and processes. } \\
\text { Educate them about new roles in the organization as well as how their own roles and } \\
\text { responsibilities may change. Introduce and welcome newcomers, ensuring that they adjust } \\
\text { quickly and comfortably. }\end{array}$ \\
\hline $\begin{array}{l}\text { Clique impact } \\
\text { discounted }\end{array}$ & $\begin{array}{l}\text { Mitigate the harmful effects of cliques. Encourage and/or arrange opportunities for } \\
\text { members of different cliques to work together on selected activities. For example, } \\
\text { individuals from different cliques could be paired together in brainstorming discussions, } \\
\text { service-related events, liaison teams, and the like. By collaborating on work-related } \\
\text { projects, individuals get to know each other better, are positioned to recognize each other's } \\
\text { strengths and skill set, and are less likely to shun or be marginalized. }\end{array}$ \\
\hline $\begin{array}{l}\text { Inadequate } \\
\text { problem solving }\end{array}$ & $\begin{array}{l}\text { Ensure consistency between the strategic plan and Board member commitment. } \\
\text { Assess Board member reaction to the finalized strategic plan. Where the fit is less than } \\
\text { ideal, discuss concerns and make decisions about continued Board service. Make clear to } \\
\text { new Board candidates expectations for serving. }\end{array}$ \\
\hline
\end{tabular}

Table 7: Lessons in maintaining unity

\section{Relentless perseveration}

Numerous Board members expressed their dismay publicly about the inability of the Board to carry out its work. One member lamented, "We are predominantly a dysfunctional board. We are getting nothing accomplished." While dysfunction was an issue, the failure to achieve tangible results also resulted from perseveration, the "tendency to continue or repeat an act or activity after the cessation of the original stimulus" (dictionary.reference.com, accessed February 28, 2015). For example, an issue would be introduced and Board members would brainstorm solutions; that same scenario might recur two months later, five months later, even 14 months later.

Perseveration resulting in inaction. Members of the Marketing Committee frequently asked that the website be kept up-to-date. They also believed that parts of it needed to be rewritten to highlight LifeTree's "signature program" in dementia care, reorganized to be user friendly, and contain new images and audio materials. Other Board members suggested reinstating LifeTree's newsletter, which had lapsed, and removing outdated issues from the website. Implementation of these changes fell to the Executive Director. None of the changes was made. This same pattern of inaction resulted in most of my requests to the Executive Director during my presidency.

Other perseveration examples revolved around the Development Director's position. One issue that surfaced at least four times between October 2012 and April 2013 concerned whether to include her salary in the annual budget; it was never resolved. A second issue involved the full 
participation of the Development Director and Community Relations Director in Board meetings. It emerged in the first quarter of 2013, and reappeared repeatedly through September. Board members with connections to the nonprofit sector wanted a more open attendance policy while those tied to the corporate sector preferred having only the Executive Director present. This division correlated highly with clique affiliation. Agreement was never reached.

Perseveration resulting in confrontation and defiance. Marketing to specific religious groups was a contested issue. The Executive Director, who was Roman Catholic, repeatedly sought ways to use the church "as a pipeline for residents," while Episcopalian Board members argued that Life Tree "should be increasing awareness...to the Episcopal Diocese." The Episcopal Bishop reinforced this latter perspective when he attended the February 2014 Board meeting. He advised that LifeTree "go back to its roots." The issue was not that the Executive Director was building relationships with Roman Catholic parish representatives, but that she was unwilling to satisfy Episcopal Board member requests. Her rebuff is reflected in the January 2014 Board minutes:

(An Episcopalian Board member) raised a longstanding question about why we are not more actively pursuing clergy and other connections with St. Dunstan's where there is a substantial elderly population. (The Executive Director) chose not to respond despite being pressed (and) indicated that she is hoping for a different platform for making connections to area clergy than the one...suggested.

Lessons

Ongoing perseveration, reflecting continuous flux in Board decisions and actions, contributed to my sense that liminality was a persistent feature of my Presidency. The Board wavered between its cost-oriented past and its potential for a philanthropic-oriented future. During this transition, it was largely impossible to accomplish the Board's work due to disagreements about what the work should be. Nevertheless, for many months, I felt it was possible to regroup and regain momentum. I gathered additional support and advice from nonprofit professionals, clergy administrators, and organizational-change researchers. However, by fall 2013, it was clear to me that I, and others supporting the development and marketing initiatives, could not arrest LifeTree's downward spiral. I began considering the only other strategy short of shutting LifeTree's doors-that of affiliation with some other senior community-and opened discussions with selected senior-community administrators. This initiative never reached fruition due to Board member trepidation. Lessons continued to surface (see Table 8). 


\begin{tabular}{|l|l|}
\hline Issue & Lesson \\
\hline $\begin{array}{l}\text { Poor procedural } \\
\text { use }\end{array}$ & $\begin{array}{l}\text { Establish and follow a structured approach to decision making. Use the finalized } \\
\text { strategic plan to guide discussions and decision making. Take full advantage of Robert's } \\
\text { Rules of Order by tracking motions and their outcomes. Follow up to ensure that the } \\
\text { motions have the resources they need and are implemented in a timely fashion. }\end{array}$ \\
\hline $\begin{array}{l}\text { Inadequate } \\
\text { prioritization }\end{array}$ & $\begin{array}{l}\text { Keep sight of the long-term goals, working with all leaders. In the event that } \\
\text { leadership persuasion fails, figure out where to compromise on "process" issues to achieve } \\
\text { organizational goals and objectives. As trust builds, contested issues are likely to be fewer } \\
\text { in number. }\end{array}$ \\
\hline $\begin{array}{l}\text { No guidelines } \\
\text { shaping Board } \\
\text { action }\end{array}$ & $\begin{array}{l}\text { Encourage open discussion of initiatives. Facilitate expression of different viewpoints, } \\
\text { rationales, and approaches. Expect that work-related activities can be explained and } \\
\text { defended satisfactorily, and that they are in compliance with the strategic plan. Challenge } \\
\text { individuals to address any biases in their reasoning, approach, or method. }\end{array}$ \\
\hline
\end{tabular}

Table 8: Lessons in keeping an eye on the prize

\section{Impact on LifeTree}

\section{Continuing deterioration}

Reliance on resident fees continued to be the only significant source of revenue. There was no budget for capital expenditures and no consistent coverage of depreciation. Only 12 weeks of operating expenses were available in the bank. The March 2014 Board decision to approve a "refresh" of public or common areas near the entrance, and the hiring of a marketing professional, were expected to stress the budget further.

\section{A lost year of potential accomplishments}

A culture of philanthropy involving LifeTree's extended community was not realized. The Board's actions and inactions reflected an unwillingness to adapt to changing external circumstances. Even simple website updating remained an elusive goal, with Marketing Committee suggestions ignored.

\section{Energy for future initiatives sapped}

The tenor at many Board and Committee meetings resulted in Board member statements about feeling "drained," "sad," "frustrated," "angry," and/or "dissatisfied." Eight Board members resigned during the field period with two other resignations by early summer, mine included. As of March 2014, surviving Board members had not expressed any willingness publicly to engage with the new marketing initiative (current President and the leadership "trio" excepted).

\section{Ineffective governance}

LifeTree's Board members, myself included, had little knowledge or understanding of the responsibilities of nonprofit boards. First, Life 
Tree's Board scored poorly on at least six of the 10 basic responsibilities including those related to organizational planning, maintaining accountability, and enhancing the organization's public standing (Ingram, 2008). It is essentially impossible to be a high-performing board without a general comprehension of nonprofit board roles and tasks. Second, the Board's decision-making process was broken. Robert's Rules of Order were used at some Board and Committee meetings but were neither consistently applied nor understood. For example, at the August Board meeting, the minutes read: "There was a motion before the Board...to hire a Development consultant to report to the Board. The motion passed unanimously." Yet about two weeks later, three members resigned from the Board because of the emphasis on development, and ultimately, the Board opted not to hire a development consultant. Third, the by-laws provided some limited guidance, but they, too, were often ignored. The Board was willing to allow the Past President to continue serving. His continued participation, ongoing "behind the scenes" assistance with LifeTree operations, and frequently voiced opposition to my Presidential vision, made it difficult for me to build a consensus to help the organization focus on the long term. Finally, no mechanisms were in place to incentivize the Executive Director to carry out Board requests. Annual raises were so minimal that they were not an effective incentive. Moreover, the Board was reluctant to let her go since no ready supply of alternative candidates existed who had both the appropriate licensure and were likely to accept a similar level of compensation.

\section{Lessons}

The complexity and struggle associated with this case study are reminders that innovation can be perceived negatively, rather than accepted as part of a creative work process or "ritual rite of passage" (Malefyt and Morais, 2012:39). The misaligned expectations and tenacity within the Board and Leadership Team represented a perfect storm of opposing interests. Still, it is important to consider lessons in evaluation outcomes (see Table 9). 


\begin{tabular}{|l|l|} 
Issue & Lesson \\
\hline $\begin{array}{l}\text { Awareness and } \\
\text { knowledge poor }\end{array}$ & $\begin{array}{l}\text { Professionalize the Board through nonprofit training. Enhance Board member } \\
\text { orientation building on the current foundation of organizational specifics. Prepare Board } \\
\text { members for their roles and responsibilities based on current best practices of nonprofit } \\
\text { boards. }\end{array}$ \\
\hline $\begin{array}{l}\text { Permitting an } \\
\text { exception to the } \\
\text { rule }\end{array}$ & $\begin{array}{l}\text { Follow the by-laws. Adhere to the "letter" of the by-laws as well as their "spirit." } \\
\text { Recognize that the by-laws were created to provide a structure on which to operate. } \\
\text { Modifications and amendments to that structure can be made, but necessitate compliance } \\
\text { with a formalized change process. }\end{array}$ \\
\hline $\begin{array}{l}\text { No performance } \\
\text { measures }\end{array}$ & $\begin{array}{l}\text { Evaluate organizational performance based on execution of the strategic plan. } \\
\text { Engage the officers in establishing explicit, measurable goals for the organization and its } \\
\text { leadership. The Executive Director is responsible for carrying out these goals successfully } \\
\text { with the appropriate resources, support, and timing. If he/she is unable to deliver to } \\
\text { expectations, the officers should reach consensus on pursuing new candidates for the } \\
\text { position. }\end{array}$ \\
\hline
\end{tabular}

Table 9: Lessons in evaluation outcomes

\section{Insights for practice}

\section{The Countering Resistance Model}

Lessons derived from LifeTree's experience are captured in the Countering Resistance Model (see Figure 3). It is designed to help organizations, particularly nonprofits, counter resistance and avoid failure. Lessons are grouped into three interdependent categories related to structure and dynamics, each with a general recommendation.

Organizations in the nonprofit sector should use the structural lessons as a general outline for change. Reliance on by-laws, division of labor, and an ability to understand another's perspective by considering that person's role, provide some guidance under conditions of turmoil, rapid change, and liminal situations. Structural lessons also establish constraints on particular actions that may not be in the best interests of the organization as a whole.

The dynamic lessons confirm that collaboration on planned change is essential in nonprofits. Understanding one's colleagues is the first step in developing a strong, healthy ability to work together. Working through the disagreements, the development of new solutions, and the agreement to disagree (and compromise) can improve organizational performance. Moreover, with an eye on stakeholder interests and the long-term, collaboration positions the organization to move in unity toward successful outcomes.

The interface lessons suggest that planned change in nonprofits must be approached systematically and carefully. Planned change begins with the creation of a strategic plan and ends with an evaluation of how well it was executed. The plan itself becomes an important element of the organizational structure - a roadmap for what to change and how quickly to change it. The ideas and feedback on the plan, as well as the work associated with it, represent the organizational dynamics. As buy-in 
increases, clique behavior diminishes, poor performance is reduced, and long-term goals have a higher likelihood of being achieved.

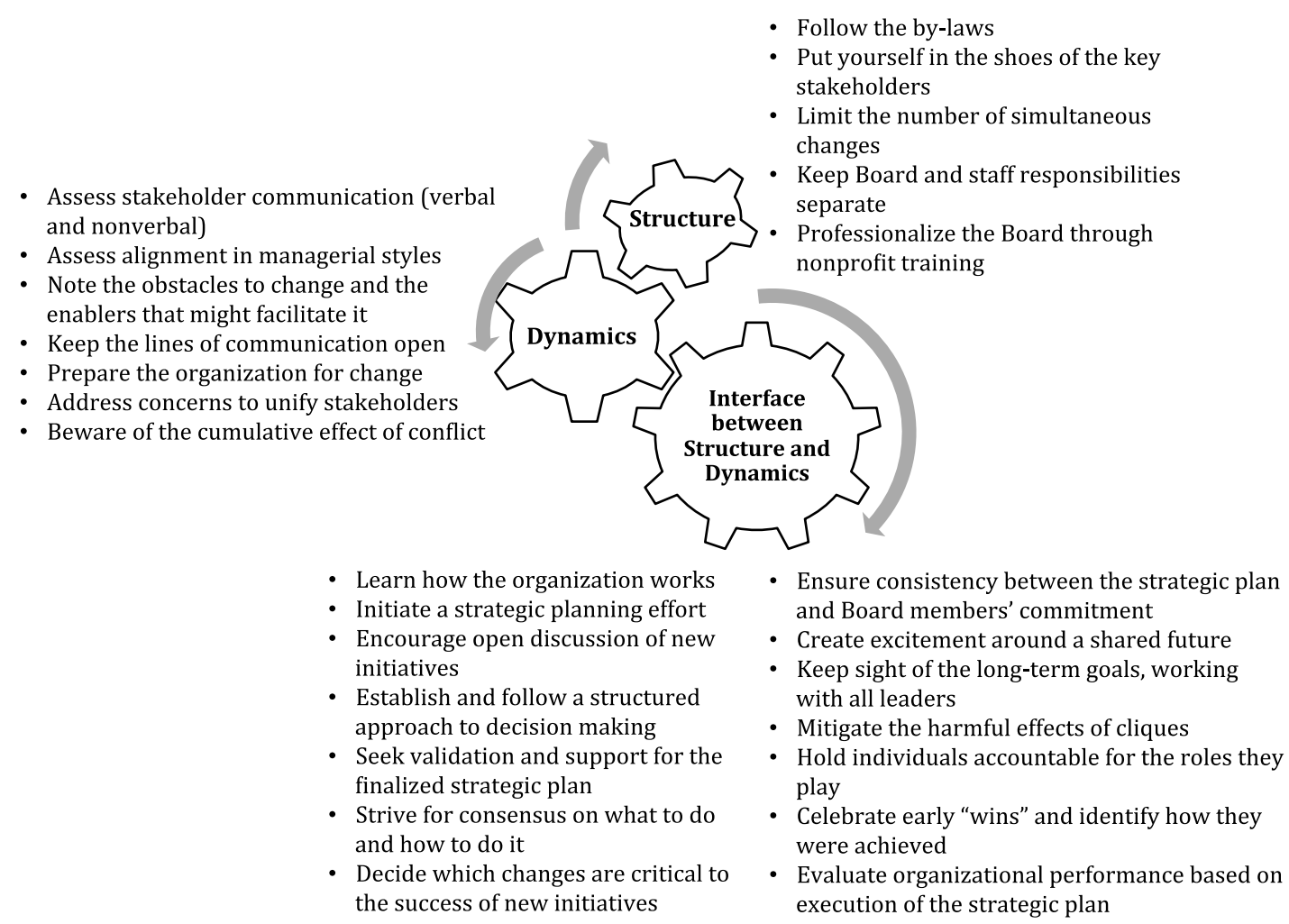

Figure 3: Countering Resistance Model

\section{General insights}

It is possible that the development and marketing initiatives could have been successful if circumstances had been different. The Board might have invited an external authority, such as the Bishop, to play a more prominent role in LifeTree's culture sooner. It might have requested diocesan financial support in the form of matching funds or seed money prior to the start of the capital campaign. Board officers might have created a shared vision for the long-term future, and then sought input and advice from other Board members. A consensus vision and cooperative relationship between the Executive Director and me might have resulted in greater success. More direct management experience might have enabled me to balance competing aims better. The officers might have held the Executive Director accountable for her actions, especially those that were unilateral and inconsistent with the future vision.

Clear from this case are certain tenets. First, dire circumstances are not enough to create momentum for change. Second, a vision for the long term is not enough to initiate change. Third, being the Board President is not enough to drive change. Fourth, having a critical mass of 
supporters-most of whom are volunteers-is not enough to sustain change. Indeed, I discovered the durability of the existing LifeTree culture-close-knit and directive with power concentrated in a few. These elements serve as a reminder that this case is not about incompatible personalities, but rather about the power of organizational culture. Indeed, they illustrate LifeTree's strength to arrest organizational change, defeating an innovation that could have put it on firm financial footing. Finally, they point to the relevance and importance of attending to "hidden" aspects of the culture, particularly when they diverge from what is observed or articulated.

To be successful, organizational-culture change must harness key organizational stakeholders in an inclusive planning process that focuses attention on the organization's future ideal and a path to achieve it. Moreover, among the elements of the organizational-culture change process are the specification of the processes and conditions that necessitate change, a guiding coalition's efforts to help steer and measure the change process, the leveraging of existing cultural enablers (that is, positive cultural processes) to address the obstacles to change encountered along the way, and the creation of mechanisms to maintain the changes achieved (Burke 2014; Briody et al., 2014; Kotter 1996). Periods in which liminality and conflict intermingle become evident, particularly when an entrenched status quo is operating at high capacity. In a recent analysis of organizational change (Briody and Erickson 2016), the presence of five factors predicted successful change: collaboration, leadership buy-in, structural change, work practice change, and evidence of benefit. At LifeTree, structural and work practice changes occurred via the hiring of the Development Director. However, leadership buy-in, Board-wide collaboration, and evidence of benefit never fully materialized.

\section{Insights for theory}

\section{Liminality in relation to organizational-culture change}

Liminality is associated with the second of three phases of a ritual-an intermediate period or state involving "waiting" (van Gennep, 1960:25) and "transition" (van Gennep, 1960:11) or "limbo" (Turner, 1988:25). The limen or threshold has been crossed. In organizational parlance, this period would be referred to as the "intervention" phase. During intervention, change is underway and is measured during the third or "post intervention" phase.

I identified three distinct types of liminality. Recurring liminality is a state or condition anticipated based on the group's activity cycle. It was associated with the periodic rotation of Board Presidents. Recurring liminality emerged when an announcement was made to Board members about a new (and likely) President-Elect. Ambiguity was embedded in 
this pre-presidential phase as ideas were formulated and plans shaped up "betwixt and between the structural past and the structural future" (Turner, 1990:11). Recurring liminality ended when the new Board President was formally elected a few months later.

Disrupting liminality is a state or condition that forms in opposition to innovation and change. Development ideas and activities ramped up about the time I became President-Elect. The more the development focus gained momentum with some Board members, the more unsettling it appeared to others. Turner's summary of liminality in modern social processes and movements highlights this particular emphasis: "...the seeds of cultural transformation, discontent with the way things are culturally, and social criticism...have become situationally central..." (1982:45). Efforts were undertaken to change - indeed, invert - certain cultural expectations and norms (e.g., fundraising over marketing, collaboration over leadership directives) but those efforts continued to be rejected by a small but critical group. Disrupting liminality continued throughout my term of office but began to wane shortly before an announcement was made of the next President-Elect.

Prophetic liminality is a state or condition overshadowing organizational functioning due to an externally imposed stipulation. It exists during a time-limited period. The state government specified the installation of a sprinkler system by 2019. Eventually, this liminal period will end when the facility complies or closes. The priority attributed to the state regulation became a contentious cultural issue. The development clique that included several former fundraisers understood the urgency in getting a capital campaign started. The marketing clique believed that there was plenty of time to raise the funds, and that if its marketing efforts improved it might not need the funds. Thus, perceptions of time and priority can vary during prophetic liminality periods.

Figure 4 illustrates these three types of liminality during the field period. All three types held great promise for the Board and for LifeTree as an organization: the "potentiality for the formation of new ideas, symbols, models, beliefs" (Turner, 1982:54). Yet, all three included some degree of risk: "To have been in the margins is to have been in contact with danger, to have been at a source of power" (Douglas, 1966:120). 


\section{Prophetic Liminality}

Disrupting timinality

\section{Recurring Liminality}

Oct Nov Dec Jan Feb Mar Apr May Jun Jul Aug Sep Oct Nov Dec Jan Feb Mar

Figure 4: Liminality types by time period

During the two periods of recurring liminality, Board President-Elects were able to describe their ideas and engage members in their planned initiatives. Indeed, Board members seemed to grant President-Elects latitude of expression and action. Recurring liminality can morph into disrupting liminality and did so under my Presidency. Development work was unsettling, even disagreeable, to a critical mass of Board members. Without an historical precedent and with the symbolic association of "danger," "dirt," or "pollution" (Douglas, 1966), development work became a lightening rod for resistance. The period of prophetic liminality continued to gain prominence over time. Just two months into his Presidency in February 2014, the new President asked the Episcopal Bishop for financial assistance.

\section{Social drama and organizational-culture change}

A period of disrupting liminality seems to be especially susceptible to conflict when it is largely incompatible with the existing culture. Turner's social drama model is a useful starting point for analyzing behavior when disagreement is high. The four-stage model helps explain the pattern of conflict that emerged sporadically during the time I was President-Elect, and subsequently characterized much of my Presidency. Moeran (2006:68) describes it as a "disharmonic social process...in which someone or some organization moves to a new place in the social order." A breach in vision and approach to the future was followed by an extended crisis, attempts to overcome disagreements, and finally dual outcomes: schism, as Board members resigned, and "actions restorative of peace" (Turner 1988:35) among those who remained.

Yet, the devil is in the details. As I juxtaposed the four stages onto key events during the field period, I discovered that the stages did not conform well to the case study. Who defines what a breach is and when it occurs? Three possible incidents might count as a breach from my perspective: (1) when a motion was made to eliminate funding for the Development Director's salary (October 2012); (2) when the Past President requested and the Board agreed to allow the Past President to 
attend Board and Executive Committee meetings, in violation of the bylaws; or (3) when the Executive Director warned me to "Go slow" (December 2012) as I was about to begin my Presidency. On the other hand, if the Executive Director had been asked what she viewed as a breach, she might have indicated results of the cultural study that she found offensive (2011), the Board's hire of the Development Director to work under her supervision (November 2012), or my attempt to build relationships with and learn from the Leadership Team (December 2012). Thus, perceptions of a breach, or series of breaches, might vary.

The crisis stage of the case study was characterized by mixed messages, flash points, perseveration, ambiguity, silence, inaction, defiance, and disregard for both the by-laws and the Board's own decisions. It was not a single event but a series of events that took their toll on the Board. I felt I was trying to lead during a chaotic time in which Board allegiance was split between the Past President and me. In addition, the marketing and operations approach was reinforced repeatedly, while the Executive Director remained unwilling to devote her energies to development. Ambiguity and perseveration continued throughout my Presidency as a result.

Evidence for both latent and manifest conflict was consistent with the social drama model. Noticeably absent from the model, however, is any recognition that interventions can and do happen in response to past and current tensions. Indeed, the model suggests a somewhat arbitrary separation between the crisis and redress stages. Yet, the case study demonstrated that conflict and attempted resolutions operated hand-inhand. For example, meetings were called with members of opposing viewpoints, prayers of reconciliation were offered, and outside counsel and expertise were sought and acted upon. This weakness of the model makes it all but impossible to understand and explain the interactive nature and cumulative potential of conflict. Moreover, it leaves the impression that disagreements and arguments are continuous and unstoppable, when they can be: (1) punctuated by repeated interventions; and/or (2) successfully argued.

By contrast, the fourth stage of the model, schism or reincorporation, generally reflects the patterns from the case study. One point worth noting is that selection to and exit from the Board was individually based. Thus, "mini schisms" or fracturing occurred within the larger Board as members resigned. Individual members had different levels of tolerance for the social drama and for co-existing with the disrupting and prophetic liminality in play. While the Board was affected by the fracturing, it retained the ability to choose new Board members. Restoration was made easier by the addition of newcomers to replace those who had left, and by the institutional rotation that brought in new members at the start of each year. 
Turner (1990:10) graphically illustrates the relationship between ritual process and social drama by showing a connection between the ritual's liminal phase and the social drama's redress phase. For him, both phases consist of "milieus detached from mundane life and characterized by the presence of ambiguous ideas... ordeals, humiliations... and many other phenomena and processes which I have elsewhere described as liminal" (1990:11). When resistance was encountered at LifeTree, attempts were made to address it and find agreed-upon solutions; if unsuccessful, the resistance was either ignored or circumvented. As I have demonstrated, liminality surrounded a combined crisis-redress stage, and "spilled over" into the periods in which breaches, schisms, and restoration occurred.

Turner does not emphasize the parallel and repetitive processes of consensus and resistance during liminal periods. Certainly consensus emerged within the Board. However, it was strongest within the cliques since members of each shared a common viewpoint and seemed to experience some degree of communitas. Indeed, both cliques extended their reach into the ranks of the Leadership Team: the clique favoring development included the Development and Community Relations Directors (early in 2013), while the clique opposing development included clinical Leadership Team members. This within-group consensus became highly visible whenever members of the opposing clique made statements or took actions threatening the other clique's stance on development. Resistance appeared across the two cliques that subsequently led to a repeated cycle of conflict within the Leadership Team, within the Board, and between both entities.

Turner's discussion of ritual and social drama describes outcomes in fairly general terms. The detail here shows that liminality can wane before ending. Moreover, the period of disrupting liminality concluded by being more "dangerous," contested, and resistant than either period of recurring liminality. The loss of more than one year in preparing for and attempting to execute a development and marketing initiative cost the organization in terms of decision making delays, rework, lost donations for "pressing capital needs," unsuccessful marketing, and fragmented Board-Leadership Team relationships. Organizations that remain in disrupting liminal transitions too long, experiencing extended periods of conflict, are unable to act in ways that fulfill their mission. Indeed, they fail themselves and their stakeholders. Of course, there may be increasing "drama" as the end of the prophetic liminality period nears, depending on the Board's response in the interim.

\section{Conclusions}

Guiding change as President of the Board was challenging and hardly rewarding. Yet, the experience positioned me to understand some foundational issues that prevented change from taking hold. Not only 
was the LifeTree Board an often-unwilling participant in three types of liminal periods described in the article, but also its members were subjected to the effects of liminality first-hand. By and large, Board members were outsiders to the day-to-day practices and activities at LifeTree. We were not "of" the long-term-care community, but rather external advisors to and supervisors of it. Thus, we were neither insiders nor outsiders-a liminal status that itself can create tension. We were like Garsten's temporary workers, in a sense, because we served in a temporary role. It was unlikely for us to become LifeTree insiders unless the organizational dynamics engaged us in an ongoing and long-term relationship, the organizational structure allowed for some flexibility and permeability, and we, as individuals, were willing to dedicate significant effort and energy to LifeTree over an extended period of time.

The Past President was different though. He shed his liminal status as an outsider and became an insider long before the Executive Director came to LifeTree. His insider status was based on 1) his longterm association with LifeTree as a former family member, Board member, and Board President, 2) his technical knowledge and skills in managing a long-term-care community, and 3) his desire to devote numerous hours/week to LifeTree. Staff, residents, and other stakeholders accepted him as a critical part of the organization.

Nonprofits rely significantly on relationships and volunteer goodwill to get the work of the organization done. Without building a more intense and effective collaboration with the Past President and Executive Director, we, as Board members, could not hope to be viewed as full (i.e., permanent, not liminal) participants in LifeTree's culture. Indeed, structural and relationship barriers would remain in place, solidifying the divide between "us" and "them" and innovative change and the status quo. Though some Board members had good relationships with insiders, these members were analogous to temporary workers; insufficient time had elapsed to demonstrate their longstanding commitment.

The Countering Resistance Model challenges change agents to focus first and foremost on key organizational relationships. Interactions leading to the development of trust are a first step in learning about the organizational culture, working effectively within it, and assisting with the organization's response to a changing external environment. Cultivating and maintaining those relationship-including those that are problematic and taxing-has the potential to mitigate the liminality associated with individual Board members by virtue of their Board role. With that constraint lifted, the challenges of the organization can be tackled with a greater likelihood of success. 


\section{Acknowledgments}

I thank the following reviewers for their helpful comments: Timothy Malefyt, Maryann McCabe, Barbara Olsen, Marc Robinson, John Bell, Tara Eaton, Chris Yaw, Sherri Briller, Leslie McNamara, Robin Eikenberry, and the $J B A$ reviewers. Their feedback helped make the article stronger.

\section{References}

Bonebright, D.A. 2010. 40 years of storming: A historical review of Tuckman's model of small group development. Human Resource Development International 13(1): 111-120.

Boussebaa, M. 2009. Struggling to organize across national borders: The case of global resource management in professional service firms. Human Relations 62(6): 829-850.

Briody, E.K. and S.H. Briller. Pursuing a desired future: Continuity and change in a long-term-care community, Journal of Applied Gerontology, forthcoming.

Briody, E.K. and K.C. Erickson. 2016. Success despite the Silos: Systemwide innovation and collaboration. In Collaborative ethnography in a business environment. M. McCabe, ed. Walnut Creek, CA: Left Coast Press, in press.

Briody, E.K., R.T. Trotter, II, and T.L. Meerwarth. 2014. Transforming culture: Creating and sustaining effective organizations. New York, NY: Palgrave Macmillan.

Burke, W.W. 2014. Organization change: Theory and practice. $4^{\text {th }}$ ed. Los Angeles, CA: Sage Publications, Inc.

Cameron, K.S. and R.E. Quinn. 2011. Diagnosing and changing organizational culture: Based on the competing values framework. $3^{\text {rd }}$ ed. San Francisco, CA: Jossey-Bass.

Chang, H. 2008. Autoethnography as method. Walnut Creek, CA: Left Coast Press.

Douglas, M. 1966. Purity and danger: An analysis of concept of pollution and taboo. London, UK: Routledge and Kegan Paul.

Ferraro, G.P. and E.K. Briody. 2013. The cultural dimension of global business. $7^{\text {th }}$ ed. Boston, MA: Pearson Education, Inc.

Garsten, C. 1999. Betwixt and between: Temporary employees as liminal subjects in flexible organizations, Organization Studies 20(4): 601-617.

Ingram, R.T. 2008. Ten basic responsibilities of nonprofit boards. Washington, DC: BoardSource. 
Jones, S.H., T.E. Adams, and C. Ellis, eds. 2013. Handbook of autoethnography. Walnut Creek, CA: Left Coast Press.

Kotter, J.P. 1966. Leading change. Boston, MA: Harvard Business School Press.

Malefyt, T. de Waal and R.J. Morais. 2012. Advertising and anthropology: Ethnographic practice and cultural perspectives. Oxford, UK: Berg.

Meschi, P-X. and U. Wassmer. 2013. The effect of foreign partner network embeddedness on international joint venture failure: Evidence from European firms' investments in emerging economies, International Business Review 22(4): 713-724.

Moeran, B. 2006. Ethnography at work. Oxford, UK: Berg.

Renz, D.O., ed. 2010. The Jossey-Bass handbook of nonprofit leadership and management. $3^{\text {rd }}$ ed., San Francisco, CA: Jossey-Bass.

Rottig, D., T.H. Reus, and S.Y. Tarba. 2013. The impact of culture on mergers and acquisitions: A third of a century of research, Advances in Mergers and Acquisitions 12: 135-172.

Rylko-Bauer, B. 2014. A Polish doctor in the Nazi camp: My mother's memories of imprisonment, immigration, and a life remade. Norman, $\mathrm{OK}$ : University of Oklahoma Press.

Tuckman, B.W. and M.A.C. Jensen. 1977. Stages of small-group development revisited. Group and Organization Management 2(4): 419427.

Turner, V. 2007. The ritual process: Structure and anti-structure. New Brunswick, NJ: Aldine Transaction.

Turner, V. 1990. Are there universals of performance in myth, ritual, and drama? In By means of performance: Intercultural studies of theatre and ritual. R. Schechner and W. Appel, eds. Cambridge, UK: Cambridge University Press, 8-18.

Turner, V. 1988. The anthropology of performance. New York, NY: PAJ Publications.

Turner, V. 1982. From ritual to theatre: The human seriousness of play. New York, NY: PAJ Publications.

van Gennep, A. 1960. The rites of passage. Translated by M.A. Vizedom and G.L. Caffee. Chicago, IL: University of Chicago Press.

Weber, Y., S.Y. Tarba, and Z. Rosen Bachar. 2011. Mergers and acquisitions performance paradox: The mediating role of integration approach. European Journal of International Management 5(4): 373-393. www.robertsrules.org 
Elizabeth K. Briody, Ph.D., is a cultural anthropologist who has been engaged in organizational-culture change for over 25 years. She is founder and principal of Cultural Keys LLC, a consultancy that helps organizations transform their culture, reach their potential, and attract and retain new customers. She has worked in health care, manufacturing, consumer products, service industries, research institutions, and other industries in the U.S. and abroad. Her most recent books include Transforming Culture: Creating and Sustaining Effective Organizations (co-authored with Robert T. Trotter, II and Tracy L. Meerwarth, Palgrave, 2014) and The Cultural Dimension of Global Business (co-authored with Gary Ferraro, 7th ed., Pearson, 2013). Elizabeth is currently a Board member of the American Anthropological Association. She may be reached at elizabeth@culturalkeys.us 